\title{
BIOMASS YIELD OF CROTALARIA JUNCEA AFTER THINNING AND AT VARIED SOWING DENSITIES IN THE COASTAL PLATEAU OF PIAUÍ STATE, BRAZIL $^{1}$
}

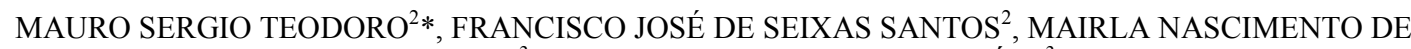 \\ LACERDA ${ }^{3}$, LUMA MELISA DA SILVA ARAÚJO ${ }^{3}$
}

\begin{abstract}
The northern region of Piauí state is an important center of irrigated organic fruit farming, wherein sandy soils with low organic matter content are predominant, besides climate with high temperatures, long periods of water deficit and constant wind. Given this situation, it becomes necessary to investigate alternative management options able to meet the challenges of agricultural productivity. In this context, green manuring becomes an important practice, mainly when using fast-growing species and with great potential for biomass production. Thus, a study was carried out at Embrapa Meio-Norte to measure Crotalaria juncea biomass yield after thinning and at various sowing densities. The evaluated parameters were plant height, stem diameter, number of branches per plant, fresh and dry weight of shoots and roots. The results showed that sowing density had no influence on plant height; however, unthinned plants reached greater heights, which might have been due to reduced competition for light. Thinning had no effect on diameters of plant stem base; on the other hand, lower planting densities promoted larger diameters also due to less competition. Likewise, the number of branches per plant was not affected by thinning, being greater at lower planting densities on account of less competition. Thinned plants achieved higher averages of fresh shoot weight. Nevertheless, shoot dry biomass was greater at higher planting densities. Furthermore, both fresh and dry weight of roots were not influenced by any of the adopted treatments.
\end{abstract}

Key words: Green manuring. Cover crops. Management.

\section{PRODUTIVIDADE DA CROTALARIA JUNCEA SOB PODAS E DENSIDADES DE SEMEADURA NOS TABULEIROS COSTEIROS DO PIAUÍ}

RESUMO - Na região norte do Estado do Piaú́, concentra-se um importante polo de fruticultura orgânica irrigada, onde há predomínio de solos com textura arenosa e baixos teores de matéria orgânica, além de clima com temperaturas elevadas, com longos períodos de déficit hídrico e vento constante. Diante desse quadro, faz-se necessário investigar formas alternativas de manejo, capazes de responder aos desafios da produção agrícola. Portanto, é relevante destacar a utilização da adubação verde, principalmente com espécies de crescimento rápido e com bom potencial de produção de biomassa. Com o objetivo de avaliar a produtividade da $C$. juncea. sob a influência de podas e densidades de semeadura, foi instalado um ensaio na Embrapa Meio-Norte. Foram avaliadas a altura das plantas, diâmetro de caule, número de ramos por planta, massa fresca e seca da parte aérea e das raízes. A densidade de semeadura não influenciou na altura das plantas, no entanto, observou-se maior altura das plantas que não foram podadas, provavelmente, em função da menor competição por luz. O diâmetro do colo das plantas não foi influenciado pelas podas, porém, foi maior na menor densidade de plantio, em função da menor competição. O número de ramos nas plantas também não foi influenciado pelas podas, entretanto, foi maior quanto menor a densidade de plantio, possivelmente em função da menor competição. Os tratamentos que receberam podas, obtiveram médias superiores de massa fresca da parte aérea. Entretanto, a massa seca da parte aérea foi superior na maior densidade de plantio. As massas fresca e seca das raízes não foram influenciadas por nenhum dos tratamentos adotados.

Palavras chave: Adubo verde. Plantas de cobertura. Manejo.

\footnotetext{
*Corresponding author

${ }^{1}$ Received for publication in 05/15/2015; accepted in 06/01/2016.

${ }^{2}$ Empresa Brasileira de Pesquisa Agropecuária; Parnaíba, PI, Brazil; mauro-sergio.teodoro@embrapa.br, francisco.seixas@embrapa.br.

${ }^{3}$ Universidade Estadual do Piauí, Campus Professor Alexandre Alves de Oliveira; Parnaíba, PI; mairllaphb@hotmail.com, lumamelisa@hotmail.com.
} 


\section{INTRODUCTION}

Since its inception, agriculture has undergone major technological changes, taking as historical milestone the Industrial Revolution, especially after World War II. The development of a technological package, based on mechanization and use of improved seeds and agrochemicals, brought significant gains in food production (COELHO, 2009); meanwhile, such upgrading has brought both socioeconomic and environmental impacts (BALSAN, 2006).

The knowledge, selection and adoption of good agricultural practices and environmental management become essential in a scenario where environmental conservation is of growing importance (VALARINI; REZENDE, 2007).

There is an important production center in the northern region of Piauí state, in Brazil, which stands for the main irrigation district of organic fruit farming in the country and one of the most important fruit growing areas of the state. Currently, there are 300 ha of irrigated acerola, coconut, cashew and watermelon.

The fragile nature of Piauí Coastal Plateaus' ecosystem makes farming a challenge to be conquered because of sandy textured soil predominance with low organic matter content and poor cation exchange capacity, in addition to high temperatures, long periods of water deficit and constant wind (MEHL et al., 2010). Given this scenario, the majority of farmers obtain inputs from external sources on the parallel market, such as vegetable straws among others, to meet their demands.

According to Derpsch et al. (1991), after introducing green manure in farming systems, the use of very sandy and nutrient-poor soils with low organic matter content has been enabled in several regions worldwide under economic viability.

Green manure is an agricultural practice consisting on planting crops species of economic interest in rotation or intercropping systems. According to Wutke et al., 2007, these plants, of annual or perennial cycle, produce residues that cover the soil surface for a certain period or year round. The same authors reported that these plants can be incorporated to soil or remained covering the soil surface after mowing.

Leguminous plants are most widely used as green manure worldwide. The reason for this preference lies on the symbiosis with atmospheric $\mathrm{N}$ fixing bacteria and high dry matter production (SILVA; MENEZES, 2007), recovering degraded areas (AZEVEDO et al., 2007), besides aiding in soil conservation and erosion control (BERTONI; LOMBARDI NETO, 2008).

For farming systems based on the use of local resources and optimization of biological processes, Crotalaria juncea should be highlighted as an important species (PEREIRA et al., 2005). This species is a fast-growing species currently recommended as green manure in rotation; it provides soil enrichment (SOUSA, 2011), increasing biomass production and biological nitrogen fixation rates (SILVA ARAUJO et al., 2010). In addition, it is possible to perform two harvests, increasing organic material production (ABBOUD; DUQUE, 1995), besides reducing biomass of spontaneous vegetation by adopting a proper plant density (PEREIRA et al., 2005).

Thus, $C$. juncea becomes an option for proper supplementation of organic matter in sandy soils; however, the knowledge of a suitable management to increase its biomass is of major importance for a rational use (MEHL et al., 2010).

Given the above, the objectives of this study were to evaluate the effects of thinning and plant density on $C$. juncea shoot and root biomass production, using a sandy soil of the Costal Plateaus of Piauí, Brazil.

\section{MATERIAL AND METHODS}

The experiment was performed from April to September of 2013, at Embrapa Meio-Norte/ UEP Parnaiba, $\left(03^{\circ} 05^{\prime} \mathrm{S} ; 41^{\circ} 46^{\prime} \mathrm{W}\right.$ and $46.8 \mathrm{~m}$ altitude). The climate is a C1dA'a' type, according to Thornthwaite and Mather (1955), which is characterized as dry sub-humid, megathermal with little water surplus and a concentration of $29.7 \%$ of potential evapotranspiration in the quarter October to December, with average relative humidity of $77.5 \%$, average rainfall of $1107 \mathrm{~mm}$, and average temperature of $27.6^{\circ} \mathrm{C}$ (BASTOS et al., 2012).

The local soil was classified as a dystrophic Yellow Latosol (Oxisol), of medium texture, typical Caatinga coastal stage. The chemical characterization $(0-20 \mathrm{~m}$ depth $)$ showed the following results: $\mathrm{pH}\left(\mathrm{H}_{2} \mathrm{O}\right)=6.70 ; \mathrm{Al}^{+++}=0.0$ $\mathrm{cmol}_{\mathrm{c}} / \mathrm{dm}^{3} ; \mathrm{Ca}^{++}=2.0 \mathrm{cmol}_{\mathrm{c}} / \mathrm{dm}^{3} ; \mathrm{Mg}^{++}=0.67 \mathrm{cmol}_{\mathrm{c}} /$ $\mathrm{dm}^{3} ; \mathrm{P}=18.50 \mathrm{mg} / \mathrm{dm}^{3}$ and $\mathrm{K}=0.15 \mathrm{cmol}_{\mathrm{c}} / \mathrm{dm}^{3}$.

Rainfall data during evaluations were recorded by the meteorological station of Parnaíba, located at the Experimental Field of Embrapa Meio-Norte (Figure 1).

The experiment was carried out in a randomized block design, with treatments arranged in a factorial scheme of $3 \times 3$ (three plant densities: 10,20 and 30 plants per linear meter and three references to thinning: 0,1 and 2 thinning) with four replications. Each plot had an available area of 2.25 $\mathrm{m}^{2}(1.5 \times 1.5 \mathrm{~m})$. The spacing adopted was $0.5 \mathrm{~m}$ between rows, totaling four rows of $1.5 \mathrm{~m}$ linear per treatment. 


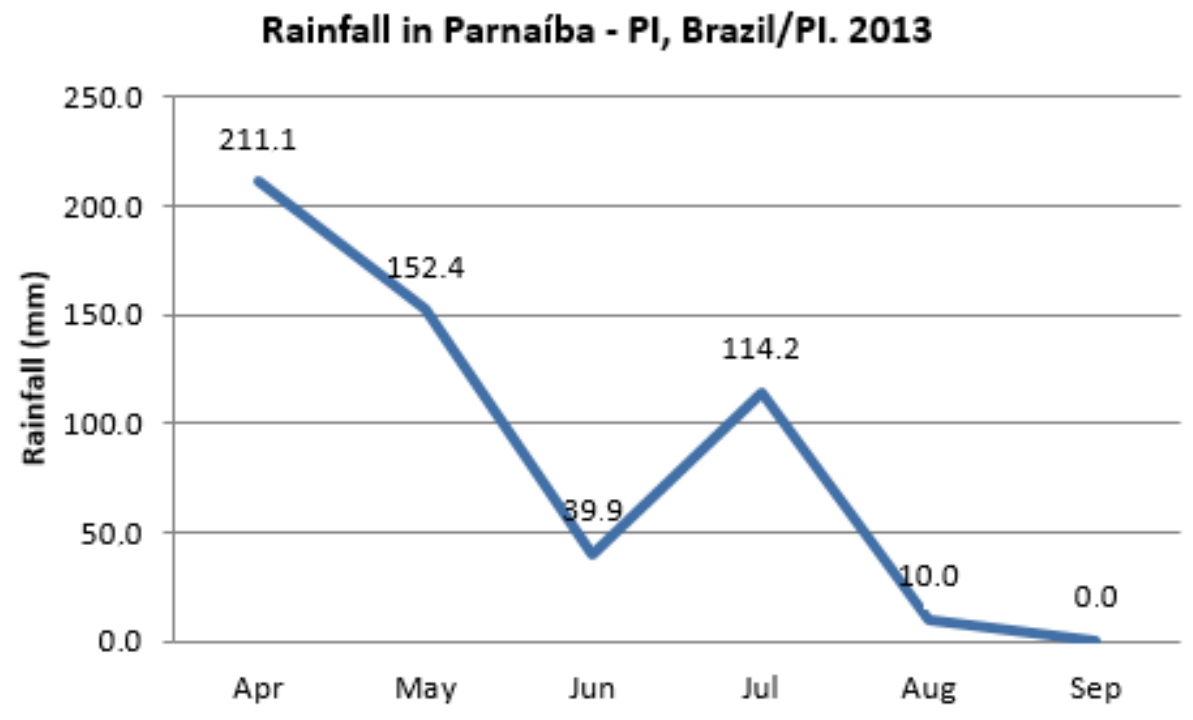

Figure 1. Average rainfall.

Soil preparation consisted of surface plowing and harrowing with subsequent manual furrowing. High sowing densities were used (approximately twice the number of seeds corresponding to each treatment), subsequently adjusting plant population by means of thinning at 20 days after sowing (DAS). Weeding was manually performed twice during the trial period.

Each net plot comprised of centerlines, i.e. discarding borders, making a total area of $0.5 \mathrm{~m}^{2}$, with 1.00 linear $\mathrm{m}$ by $0.5 \mathrm{~m}$ between rows. Thinnings were performed manually with appropriate shears; the first was carried out at 60 days after seedling emergence ( $1^{\text {st }}$ thinning), and the second after 30 days of new sprouting. Cuts were made at a reference height of $1.00 \mathrm{~m}$. Samples from both thinnings were weighed for calculations of fresh biomass, being then placed in forced ventilation oven at $65^{\circ} \mathrm{C}$ for 48 hours to determine dry biomass.

The final cuttings of all treatments were performed after 150 days of beginning experiment, being made at $0.05 \mathrm{~m}$ above the ground surface. Also, soil samples were manually collected with the aid of a hoe, at a depth of $0.20 \mathrm{~m}$. These samples passed through a fine mesh sieve $(2.0 \mathrm{~mm})$ for removal of roots from other materials, being then weighted to obtain fresh root biomass, and placed in a forced ventilation oven at $65^{\circ} \mathrm{C}$ for 48 hours to determine its dry biomass production. Concurrently, measurements of plant height $(\mathrm{PH})$; stem diameter or stem base (SD); number of branches per plant (NBP); shoot fresh biomass (SFB); shoot dry biomass (SDB); fresh root weight (RFB) and dry root weight $(\mathrm{RDB})$ were carried out.

Plant height was taken with a measuring tape, stem diameter with a caliper at plant base. Then the number of branches/ plant was accounted. Hereupon, all the material, both from the shoot and root, was weighed on a precision scale to obtain fresh biomass (SFB and RFB), and subsequently put into paper bags to be taken to a forced ventilation oven, remaining at $65^{\circ} \mathrm{C}$ for 48 hours until constant weight to determine dry biomass production (SDB, and RDB).

The data were tabulated and underwent variance analysis using the software ASSISTAT, and the means compared by applying the Tukey's test at $5 \%$ probability.

\section{RESULTS AND DISCUSSION}

Table 1 shows that there was no significant interaction between thinning and sowing densities $(p>0.05)$ for any of the analyzed variables. Sowing density had no significant effect on plant height, but promoted a slight increase in the means, in absolute values, which might have occurred due to the competition for light. The average plant height of unthinned plants was higher compared to thinned ones, being near $0.26 \mathrm{~m}$ higher than the treatment with one thinning. Eiras (2010) obtained a similar result studying the same legume, in which the author reported a variance of $0.63 \mathrm{~m}$ upward for unthinned plants; however, the author observed similar averages of diameters for both thinned and unthinned crotalaria plants. Dourado et al. (2001) had also recorded significantly higher plant height $(2.74 \mathrm{~m})$ in unthinned plants.

Table 2 reveals that there was no effect of thinning on base diameter (stem base) of $C$. juncea plants. The base stem diameter obtained at a density of 10 plants per linear meter was higher than in the other treatments, observing a diameter variation of 0.11 to $0.17 \mathrm{~mm}$ compared with other sowing densities, not differing from each other $(\mathrm{p}>0.05)$. This result was similar to that found by Eiras (2010), but unlike the one obtained by Dourado et al. (2001), in which the highest mean $(10.30 \mathrm{~mm})$ occurred in unthinned plants. 
M. S. TEODORO et al

Table 1. Sowing density and thinning influences on the height $(\mathrm{m})$ of Crotalaria juncea.

\begin{tabular}{lcccc}
\hline \multirow{2}{*}{ Thinnings } & \multicolumn{3}{c}{ Density } & Means \\
\cline { 2 - 5 } & 10 & 20 & 30 & $1.57 \mathrm{a}$ \\
\hline No thinning & 1.52 & 1.55 & 1.65 & $1.32 \mathrm{~b}$ \\
Thinning at 60 days & 1.33 & 1.33 & 1.29 & $1.27 \mathrm{~b}$ \\
Thinning at 60 days +30 days & 1.22 & 1.27 & 1.33 & \\
\hline Means & $1.36 \mathrm{~A}$ & $1.38 \mathrm{~A}$ & $1.42 \mathrm{~A}$ & 5.26 \\
\hline CV\% & & & & \\
\hline
\end{tabular}

Means followed by the same lowercase letters in columns and capitals in rows do not differ from each other from each other $(\mathrm{P}>0.05)$ by the Tukey test.

Table 2. Sowing density and thinning influences on the base diameter (mm) of Crotalaria juncea

\begin{tabular}{|c|c|c|c|c|}
\hline \multirow[t]{2}{*}{ Thinnings } & \multicolumn{4}{|c|}{ Density } \\
\hline & 10 & 20 & 30 & Means \\
\hline No thinning & 0.43 & 0.25 & 0.21 & $0.30 \mathrm{a}$ \\
\hline Thinning at 60 days & 0.39 & 0.30 & 0.20 & $0.30 \mathrm{a}$ \\
\hline Thinning at 60 days +30 days & 0.35 & 0.28 & 0.25 & $0.29 \mathrm{a}$ \\
\hline Means & $0.39 \mathrm{~A}$ & $0.28 \mathrm{~B}$ & $0.22 \mathrm{~B}$ & \\
\hline $\mathrm{CV} \%$ & & & 22.69 & \\
\hline
\end{tabular}

Means followed by the same lowercase letters in columns and capitals in rows do not differ from each other $(\mathrm{P}>0.05)$ by the Tukey test.

Regarding the number of branches, Table 3 demonstrates that thinning had no significant effect ( $\mathrm{p}>0.05$ ); nevertheless, confluent densities promoted higher absolute values. These results corroborate those obtained by Dourado et al. (2001), who worked in a dystrophic clayey Red Latosol (Oxisol), stating that thinning has no effect on the number of branches in this species. A steady increase is observed among treatments, with means ranging from 2.81 to 4.19 branches per plant, an increase of over $33 \%$ in terms of the studied spacing. Eiras (2010) reported inferior results when comparing denser spacing (20 to 30 plants per linear meter) to sparse ones (10 to 15 plants per linear meter), supporting a possible competition among plants.

Table 3. Sowing density and thinning influences on the number of branches per Crotalaria juncea plant.

\begin{tabular}{lcccc}
\hline \multirow{2}{*}{ Thinnings } & \multicolumn{3}{c}{ Density } \\
\cline { 2 - 5 } & 10 & 20 & 30 & Means \\
\hline No thinning & 4.38 & 3.48 & 2.77 & $3.54 \mathrm{a}$ \\
Thinning at 60 days & 3.88 & 3.27 & 2.86 & $3.34 \mathrm{a}$ \\
Thinning at 60 days + 30 days & 4.31 & 3.80 & 2.80 & $3.64 \mathrm{a}$ \\
\hline Means & $4.19 \mathrm{~A}$ & $3.52 \mathrm{~B}$ & $2.81 \mathrm{C}$ & \\
\hline CV\% & & & 19.81 & \\
\hline
\end{tabular}

Means followed by the same lowercase letters in columns and capitals in rows do not differ from each other $(\mathrm{P}>0.05)$ by the Tukey test.

Table 4 displays significant differences in shoot fresh biomass $(\mathrm{p}>0.05)$ for plants under thinning compared to its absence. Although there was no difference between thinning intervals, thinned plants were superior when compared to those without thinning. By checking the means, no significant difference can be observed among the different sowing densities. Dourado and Almeida (1998) conducted an experiment in Selvíria - MS (Brazil) relating thinning heights to $C$. juncea population stands; they could note that thinnings at both 0.8 and $1.0 \mathrm{~m}$ of height had no effect on total biomass yield when compared to treatments without thinning. Additionally, Abboud and Duque (1995), when studying legumes with potential for green manure during the dry season, also affirmed the same finding. These authors demonstrated that if farmers wanted to harvest green manure at the blooming period, as commonly recommended, it would be possible to perform two cuts before harvesting, thus increasing organic material production. Furthermore, Puiatti et al. (2015) observed that larger quantities of fresh and dry phytomass, as well as carbon and nutrients are provided by crotalaria cut or thinned at 135 and 165 days after sowing, reporting yields of 21.0 and 15.25 t.ha ${ }^{-1}$, respectively. Corroborating these results, the highest mean for SFB (23.8 t.ha ${ }^{-1}$ ) was obtained in treatments where both thinnings occurred within 30-day interval, highlighting it as the best span for achievement great $C$. juncea shoot fresh biomass yield in the study area. 
M. S. TEODORO et al

Table 4. Sowing density and thinning influences on the shoot fresh biomass (t.ha $\left.{ }^{-1}\right)$ of Crotalaria juncea

\begin{tabular}{lcccc}
\hline \multirow{2}{*}{ Thinnings } & \multicolumn{3}{c}{ Density } \\
\cline { 2 - 5 } & 10 & 20 & 30 & Means \\
\hline No thinning & 16.0 & 14.8 & 14.6 & $15.2 \mathrm{~b}$ \\
Thinning at 60 days & 18.4 & 24.2 & 24.0 & $22.2 \mathrm{a}$ \\
Thinning at 60 days +30 days & 16.6 & 25.2 & 29.6 & $23.8 \mathrm{a}$ \\
\hline Means & $17.0 \mathrm{~A}$ & $21.4 \mathrm{~A}$ & $22.8 \mathrm{~A}$ & \\
\hline CV\% & & & 32.07 & \\
\hline
\end{tabular}

Means followed by the same lowercase letters in columns and capitals in rows do not differ from each other $(\mathrm{P}>0.05)$ by the Tukey test.

Concerning shoot dry biomass, there were significant differences $(\mathrm{p}>0.05)$, as seen in Table 5 . It can be observed that the higher the sowing density, the greater the shoot dry weight. In addition, thinning had no influence on dry weight averages. Crotalaria effectiveness as a green manure essentially depends on plant biomass production under local conditions (WUTKE et al., 1993). Lima et al. (2010) evaluated plant spatial arrangement, density and sowing time for three green manures; they observed that regardless of the sowing density, crotalaria was the most efficient species in dry biomass accumulation. The same authors noted that the largest dry matter accumulations occurred at the lowest density $\left(500,000\right.$ plants/ha), registering yields of 16 t.ha $^{-1}$ dry weight. Ricci et al. (2005), studying the same green manures sown in November, found production of 15 t.ha ${ }^{-1}$ dry weight, the same yield was reported by Silva et al. (2002). Pereira et al. (2005) observed in spring-summer season that dry biomass yield of crotalaria was raised with increasing plant densities and reduced row spacing, reaching a yield of $10.7 \mathrm{t}^{-1} \mathrm{a}^{-1}$, obtained with rows spaced at $0.30 \mathrm{~m}$, at a density of 30 plants per linear meter. The same author evaluated the fall-winter season and observed a yield of $6.8 \mathrm{t}^{\mathrm{h}} \mathrm{ha}^{-1}$, with rows spaced at $0.30 \mathrm{~m}$ and density of 40 plants per linear meter. In our study, which was conducted between the months of April and September, an average yield of 13.2 t.ha $^{-1}$ was reached, using rows spaced at $0.50 \mathrm{~m}$ and density of 30 plants per linear meter (Table 5). Our results were consistent with those presented by Wutke (1993), with a variation of 10 to 15 t.ha $^{-1}$. Based on these outcomes, we may state that sowing density will guide the desired result for dry biomass production, being a density of 30 plants per linear meter best recommended for this species.

Table 5. Sowing density and thinning influences on the shoot dry biomass (t.ha $\left.{ }^{-1}\right)$ of Crotalaria juncea.

\begin{tabular}{lcccc}
\hline \multirow{2}{*}{ Thinnings } & \multicolumn{3}{c}{ Density } & Means \\
\cline { 2 - 5 } & 10 & 20 & 30 & 12.0 \\
\hline No thinning & 12.6 & 10.4 & 13.2 & 12.4 \\
Thinning at 60 days & 10.6 & 13.6 & 13.0 & 13.0 \\
Thinning at 60 days + 30 days & 6.8 & 13.6 & 18.8 & \\
\hline Means & $10.0 \mathrm{~B}$ & $12.6 \mathrm{AB}$ & $15.0 \mathrm{~A}$ & \\
\hline CV\% & & & 37.20 & \\
\hline
\end{tabular}

Means followed by the same lowercase letters in columns and capitals in rows do not differ from each other $(\mathrm{P}>0.05)$ by the Tukey test.

Plant roots were manually removed up to a depth of $0.20 \mathrm{~m}$ to obtain fresh and dry weight. According to Calegari et al. (1992), root production can be underestimated owning to the difficulty in collecting the entire root system, since some legumes can penetrate several meters deep into ground. Wutke (1993) reported that $C$. juncea roots might reach depths of up to $4.5 \mathrm{~m}$ after 130 days, being $79 \%$ of that within the first $0.30 \mathrm{~m}$ depth. Even though there were no significant differences among treatments for fresh root weight $(\mathrm{p}>0.05)$ (Table 6), the highest absolute value was observed for the most scattered sowing density. Costa and Melo (2012) stated that as the number of plants per square meter is increased, there is a trend of higher biomass yields.

Similarly, there were no significant differences among treatments for accumulation of root dry matter (Table 7). Conversely, increasing sowing densities obtained the highest absolute values of dry matter. Interestingly, Sousa (2011) reported a linear decrease in root dry biomass due to high competition among plants; however, the authors reported values uncommonly found in green manuring. Espíndola et al. (1998) obtained a production of $0.57 \mathrm{t}^{-h^{-1}}$ of crotalaria dry root weight, which is close to the one recorded in our study, whose sowing density means ranged from 1.0 t.ha ${ }^{-1}$ to a little less than 1.2 t.ha $^{-1}$. 
M. S. TEODORO et al.

Table 6. Sowing density and thinning influences on the fresh root weight $\left(\mathrm{t}_{\mathrm{h}} \mathrm{a}^{-1}\right)$ of Crotalaria juncea.

\begin{tabular}{lcccc}
\hline \multirow{2}{*}{ Thinnings } & \multicolumn{3}{c}{ Density } & Means \\
\cline { 2 - 5 } & 10 & 20 & 30 & 1.65 \\
\hline No thinning & 1.93 & 1.36 & 1.66 & 1.66 \\
Thinning at 60 days & 1.50 & 1.82 & 1.66 & 1.69 \\
Thinning at 60 days +30 days & 1.06 & 2.00 & 1.05 & \\
\hline Means & $1.50 \mathrm{~A}$ & $1.71 \mathrm{~A}$ & 49.91 & \\
\hline CV\% & & & 42.91 & \\
\hline
\end{tabular}

Means followed by the same lowercase letters in columns and capitals in rows do not differ from each other $(\mathrm{P}>0.05)$ by the Tukey test.

Table 7. Sowing density and thinning influences on the dry root weight $\left(\mathrm{t}_{\mathrm{h}} \mathrm{ha}^{-1}\right)$ of Crotalaria juncea.

\begin{tabular}{lcccc}
\hline \multirow{2}{*}{ Thinnings } & \multicolumn{3}{c}{ Density } & Means \\
\cline { 2 - 5 } & 10 & 20 & 30 & $1.04 \mathrm{a}$ \\
\hline No thinning & 1.15 & 0.91 & 1.07 & $1.08 \mathrm{a}$ \\
Thinning at 60 days & 1.18 & 0.96 & 1.09 & $1.07 \mathrm{a}$ \\
Thinning at 60 days + 30 days & 0.66 & 1.23 & 1.32 & \\
\hline Means & $1.00 \mathrm{~A}$ & $1.03 \mathrm{~A}$ & $1.16 \mathrm{~A}$ & \\
\hline CV\% & & & 40.94 & \\
\hline
\end{tabular}

Means followed by the same lowercase letters in columns and capitals in rows do not differ from each other $(\mathrm{P}>0.05)$ by the Tukey test.

\section{CONCLUSION}

The height averages of unthinned plants were higher than those found for unthinned plants;

The largest plant base diameter was observed in the lowest sowing density;

The smaller the sowing density, the higher the number of branches per plant;

Treatments receiving thinnings yielded more shoot fresh biomass;

The higher the sowing density, the greater the shoot dry biomass;

Fresh and dry weight of roots showed no influence from any of the treatments.

\section{REFERENCES}

ABBOUD, A. C. S.; DUQUE, F. F. Caracterização de leguminosas com potencial para a adubação verde no período da seca. In: CONGRESSO BRASILEIRO DE CIÊNCIA DO SOLO, 24., Campinas, 1995. Anais... Campinas: Sociedade Brasileira de Ciência do Solo, 1995. p. 99-100.

AZEVEDO, R. L.; RIBEIRO, G. T.; AZEVEDO, C. L. L. Feijão Guandu: Uma Planta Multiuso. Revista da Fapese, Aracajú, v. 3, n. 2, p. 81-86. 2007.

BALSAN, R. Impactos decorrentes da modernização da agricultura brasileira. CAMPO-TERRITÓRIO: revista de geografia agrária, Uberlândia, v. 1, n. 2, p. 123-151, 2006.

BASTOS, E. A.; ANDRADE JUNIOR, A. S. de; RODRIGUES, B. H. N. Boletim agrometeorológico de 2011 para o município de Parnaíba, Piauí.
Teresina: Embrapa Meio-Norte, 2012. 37 p. (Documentos, 221).

BERTONI, J; LOMBARDI NETO, F. Conservação do Solo, $7^{\text {a }}$ Edição, Editora Ícone. São Paulo, SP. 2008, 355 p.

CALEGARI, A. et al. Aspectos gerais da adubação verde. In: COSTA, M. B. B. (Ed.). Adubação verde no sul do Brasil. Rio de Janeiro: AS-PTA, 1992. p. $1-55$.

COELHO, E. M.; LEE, F. Agricultura e meio ambiente: um contrassenso? Extensão e Cultura (UFG), v. 7, p. 46-52, 2009.

COSTA E MELO, I. G. Densidades de semeadura de leguminosas na melhoria da qualidade do solo e na produtividade do milho. 2012. 60 f. Dissertação (Mestrado em Ciência do Solo: Área de Manejo e Conservação do Solo) - Universidade Federal Rural do Semi-Árido, Mossoró, 2012.

DERPSCH, R. et al. Controle da erosão no Paraná, Brasil: sistemas de cobertura de solo, plantio direto e preparo conservacionista do solo. Eschborn: GTZ, 1991. 272 p.

DOURADO, M. C.; ALMEIDA, C. R. Comportamento da Crotalaria juncea L. quando associada a três diferentes alturas de poda e duas densidades de plantas. In: CONGRESSO DE INICIAÇÃO CIENTÍFICA, 10., Araraquara, 1998. Anais... São Paulo: CNPq, 1998. p. 335.

DOURADO, M. C.; BENETOLI, T. R.; BOLONHEZI, A. C. Matéria seca e produção de 
grãos de Crotalaria juncea L. submetida à poda e adubação fosfatada. Scientia Agrícola, Piracicaba, v. 58, n. 2, p. 287-293, 2001.

EIRAS, P. P. Avaliação de diferentes densidades de semeadura e da poda na produção de sementes de Crotalaria juncea L. 2010, 55 f. Dissertação (Mestrado em Ciências e Tecnologias Agropecuárias: Área de Produção Vegetal) Universidade Estadual do Norte Fluminense, Campos dos Goytacazes, 2010.

ESPINDOLA, J. A. A. et al. Influência da adubação verde na colonização micorrízica e na produção da batata-doce. Pesquisa Agropecuária Brasileira, Brasília, v. 24, n. 2, p. 339-347, 1998.

LIMA, D. J. et al. Arranjo espacial, densidade e época de semeadura no acúmulo de matéria seca e nutrientes de três adubos verdes. Pesquisa Agropecuária Tropical, Goiânia, v. 40, n. 4, p. 531540, 2010.

MEHL, H. U. et al. Produção de biomassa e padrão de decomposição de adubos verdes cultivados nas entrelinhas de acerola orgânica. In: REUNIÃO BRASILEIRA DE MANEJO E CONSERVAÇÃO DO SOLO E DA ÁGUA, 18., 2010, Teresina. Novos caminhos para agricultura conservacionista no Brasil. Teresina: Embrapa MeioNorte: Universidade Federal do Piauí, 2010. 4 p. 1 CD-ROM.

PEREIRA, A. J. et al. Desempenho Agronômico de Crotalaria juncea em Diferentes Arranjos Populacionais e Épocas do Ano. Brasília: Embrapa, 2005. 4 p. (Comunicado Técnico, 82).

PUIATTI, M. et al. Consorciação de taro e crotalária maneja com corte rente ao solo e poda na altura do dossel. Revista Ceres, Viçosa, v. 62, n. 3, p. 275283, 2015.

RICCI, M. S. F. et al. Growth rate and nutritional status of an organic coffee cropping system. Scientia Agricola, Piracicaba, v. 62, n. 2, p. 138-144, 2005.

SILVA ARAUJO, E. da et al. Balanço de nitrogênio em área de produção de sementes de crotalária juncea nas condições da Baixada Fluminense. Rio de Janeiro: Embrapa, 2010. 14 p. (Boletim de Pesquisa, 66).

SILVA, J. A. A. et al. Reciclagem e incorporação de nutrientes ao solo pelo cultivo intercalar de adubos verdes em pomar de laranjeira-'Pêra'. Revista Brasileira de Fruticultura, Jaboticabal, v. 24, n. 1, p. 225-230, 2002.

SILVA, T. O.; MENEZES, R. S. C. Adubação orgânica da batata com esterco e, ou, Crotalaria juncea. II - Disponibilidade de N, P e K no solo ao longo do ciclo de cultivo. Revista Brasileira de Ciência do Solo, Viçosa, v. 31, n. 1, p. 51-61, 2007.

SOUSA, G. M. M. Adubação orgânica e densidades de plantas em Crotalaria juncea antecedendo arroz. 2011. 48 f. Dissertação (Mestrado em Ciência do Solo: Área de Concentração em Ciência do Solo) - Universidade Federal Rural do Semi-Árido, Mossoró, 2011.

VALARINI, P. J.; RESENDE, F. V. Sustentabilidade do manejo orgânico e convencional na produção de hortaliças do Distrito Federal. Brasília: Embrapa, 2007. 12 p. (Circular Técnica, 49).

ThORnTHWAite, C. W.; MATHER, J. R. The water balance. Centerton: Drexel Institute of technology, 1955. 104 p. (Drexel Institute of technology. Publication in climatology, v. 8, n. 1).

WUTKE, E. B.; BULISANI, E. A.; MASCARENHAS, H. A. A. I Curso Sobre Adubação Verde no Instituto Agronômico de Campinas. Campinas: IAC, 1993. 121 p. (Documento, 35).

WUTKE, E. B. et al. Bancos Comunitários de sementes de adubos verdes: informações técnicas. Brasília: MAPA, 2007. 52 p. 